\title{
Structure and kinematics of the Jungfrau syncline, Faflertal (Valais, Alps), and its regional significance
}

\author{
Thomas Krayenbuhl ${ }^{1} \&$ Albrecht STECK ${ }^{2}$
}

Key words: Alps, nappe tectonics, fold nappes, ductile deformation

\begin{abstract}
The formation and structural evolution of the Jungfrau syncline is described, based on excellent outcrops occurring in the Lötschental, in the Central Alps of Switzerland. The quality of the outcrops allows us to demonstrate that the External Massifs of the Swiss Alps have developed due to internal folding.

The Jungfrau syncline, which separates the autochtonous Gastern dome from the Aar massif basement gneiss folds, is composed of slivers of basement rocks with their Mesozoic sedimentary cover. In the Inner Faflertal, a side valley of the Lötschental, the $200 \mathrm{~m}$ thick syncline comprises four units, the Gastern massif with a reduced Mesozoic sedimentary cover in a normal stratigraphic succession, two units of overturned basement rocks with their Mesozoic sedimentary cover, and the overturned lower limb of the Tschingelhorn gneiss fold of the Aar massif with lenses of its sedimentary cover. Stratigraphy shows that the lower units, related to the Gastern massif, are condensed and that the upper units, deposited farther away from a Gastern paleo-high, form a more complete sequence, linked to the Doldenhorn Meso-Cenozoic basin fill. The integration of these local observations with published regional data leads to the following model. On the northern margin of the Doldenhorn basin, at the northern fringe of the Alpine Tethys, the pre-Triassic crystalline basement and its Mesozoic sedimentary cover were folded by ductile deformation at temperatures above $300{ }^{\circ} \mathrm{C}$ and in the presence of high fluid pressures, as
\end{abstract}

the Helvetic and Penninic nappes were overthrusted towards the northwest during the main Alpine deformation phase. The viscosity contrast between the basement gneisses and the sediments caused the formation of large basement anticlines and tight sedimentary synclines (mullion-type structures). The edges of basement blocks bounded by pre-cursor SE-dipping normal faults at the northwestern border of the Doldenhorn basin were deformed by simple shear, creating overturned slices of crystalline rocks with their sedimentary cover in what now forms the Jungfrau syncline. The localisation of ductile deformation in the vicinity of pre-existing SE-dipping faults is thought to have been helped by the circulation of fluids along the faults; these fluids would have been released from the Mesozoic sediments by metamorphic dehydration reactions accompanied by creep and dynamic recrystallisation of quartz at temperatures above $300{ }^{\circ} \mathrm{C}$. Quantification of the deformation suggests a strain ellipsoid with a ratio $\left(1+\mathrm{e}_{1} / 1+\mathrm{e}_{3}\right)$ of approximately 1000 .

The Jungfrau syncline was deformed by more brittle NW-directed shear creating well-developed shear band cleavages at a late stage, after cooling by uplift and erosion. It is suggested that the external massifs of the Alps are basement gneiss folds created at temperatures of $300{ }^{\circ} \mathrm{C}$ by detachment through ductile deformation of the upper crust of the European plate as it was underthrusted below the Adriatic plate.

\section{Introduction}

The structural relation between the external crystalline Alpine massifs of Aiguilles Rouges, Mont Blanc, Gastern, Aar and Gotthard is still debated in the Alpine geological literature. The question is: how did the External Crystalline Massifs develop? Are they:

- basement thrusts (Boyer \& Elliot 1982; Butler et al. 1986; Butler 1990), or

- basement folds (Steck 1968, 1984, 1987, 1990; Milnes \& Pfiffner 1977; Escher et al., 1988, 1993, 1997; Epard, 1990; Epard \& Escher, 1996; Escher \& Beaumont, 1997; Steck et al., 1999, 2001).
The concept of folded basement gneisses and fold nappes that are juxtaposed and linked by real synclines was first suggested by Argand ("synclinaux de raccord", 1911, 1916). Argand's model was based on the geometry of the frontal anticlines and the symmetry between the fold limbs of the crystalline nappes of the Western Penninic Alps. The frontal part of the basement fold nappes are often well exposed in the Alps and their interpretation as fold hinges is conclusive. Good examples are the Aar and Gotthard massif folds or the Antigorio, Monte Leone and Siviez - Mischabel fold nappes (Escher et al. 1988, 1993; Escher and Beaumont 1997; Genier et al. 2008). Pfiffner et al. (1997a, b \& c) illustrate in their geological profiles through the external massifs the well exposed Aar massif basement folds

\footnotetext{
${ }^{1}$ Thomas Krayenbuhl, Van Hoornebeekstraat 45, 2582 RB Den Haag, The Netherlands. E-mail: Thomas.krayenbuhl@shell.com

${ }^{2}$ Corresponding address: Albrecht Steck, Institute of Mineralogy and Geochemistry, Anthropole, Lausanne University, CH-1015 Lausanne, Switzerland.

E-mail: Albrecht.Steck@unil.ch
} 

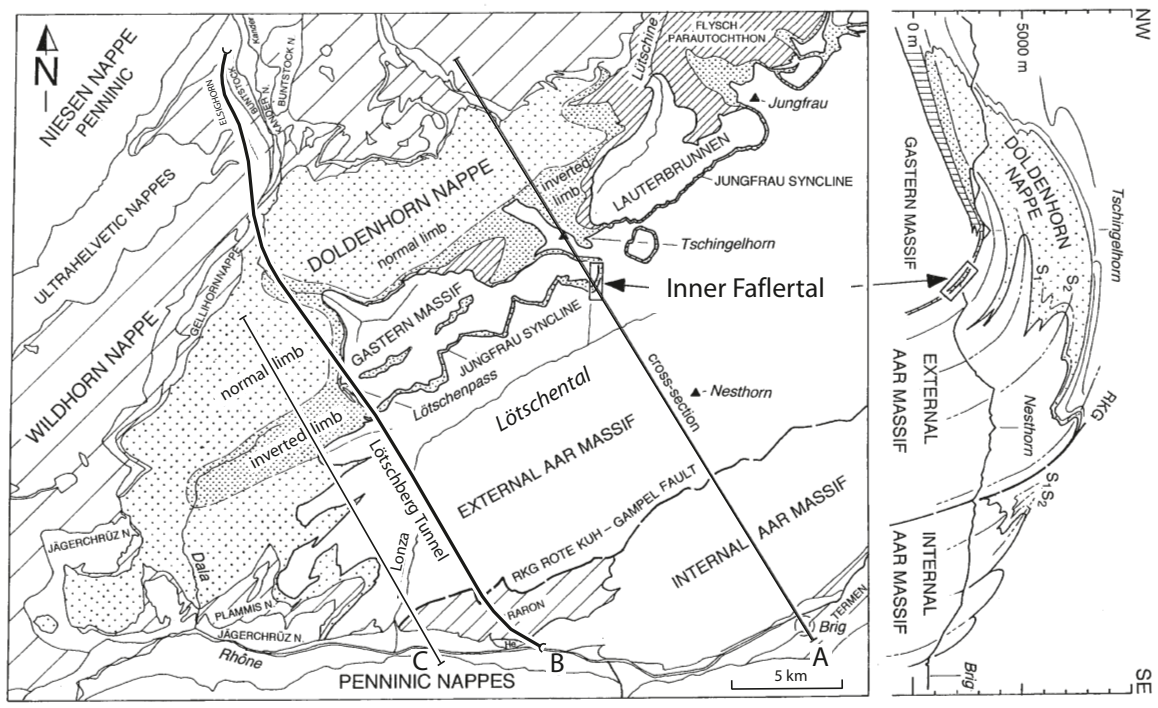

Fig. 1. Geological sketch and cross-section of the western Aar massif and its autochthonous and allochthonous Mesozoic sedimentary cover units, indicating the geographic position of the Jungfrau syncline and the studied area in the Inner Faflertal (Lötschental, Valais, Switzerland). and on the same profiles a basement thrust of the Gastern massif situated at a deeper tectonic level. The existence of this Gastern thrust is not impossible. However, we think it more likely that the overthrusted Gastern massif forms a recumbent gneiss fold, detached by ductile deformation from the subducting European crust, similar to the fold suggested by Escher et al. (1993) for the Aiguilles Rouges massif. A possible mechanism of ductile detachment by simple and pure shear is discussed in Escher and Beaumont (1997). Ramsay (1967) suggested that the folded surface of the Belledonne massif in the French Alps, with its open anticlines and pinched synclines, is an example of ductile deformation of the contact between two materials of contrasting viscosity (mullions): the competent basement gneiss and the incompetent calcareous cover sediments. However, these observations do not solve the problem of the nature of the synclinal structures at the borders of the external massifs and between the fold nappes: are they real synclinal folds or thrust faults, or some complex combination of folding and thrusting? The Lötschental, in the Canton of Valais, Switzerland, offers the opportunity to study one of these structures, the so-called "Jungfrau Keil", or Jungfrau zone or syncline, in excellent outcrops. The Jungfrau syncline is an up to $300 \mathrm{~m}$ wide zone, composed of slices of Mesozoic sediments and basement, that separates the autochthonous Gastern basement dome from the external Aar massif over a distance of $20 \mathrm{~km}$ along strike (Fig. 1). The aim of the present study was to decipher the structural history, kinematics and metamorphic conditions of this complex zone. We demonstrate that the Jungfrau syncline represents a real synclinal fold that links the Gastern basement dome with the Aar massif basement gneiss folds. This local model leads to a regional kinematic model for the formation of basement gneiss folds and fold nappes in the Alps.

\section{Geological setting}

In the study area, a 100-300 m wide zone composed of slices of Mesozoic sediments and basement rocks represents the Jungfrau syncline, separating the crystalline basement of the Gastern - Lauterbrunnen massifs from those of the Aar massif in the Helvetic domain of the Swiss Alps (Fig. 2, section A). The zone was investigated by Lugeon (1914-18) in the Ferdenrothorn - Balmhorn transect (Fig. 2, sections B and C, Tab. 1) and by Collet and Paréjas (1931) between the type-locality at the Jungfraujoch to the east and the Inner Faflertal in the upper Lötschental to the west (Fig. 1). Collet and Paréjas (1931) observed in the Inner Faflertal that the mylonitic basement slices of this zone are underlain by an overturned autochthonous succession of Triassic and Jurassic sediments and concluded that this rotation was the result of folding. The Jungfrau syncline was mapped at a 1:25'000 scale by Hügi et al. (1988). The syncline was studied in great detail by Krayenbuhl (1984) in the Inner Faflertal and Crestin (1990) in the Lötschpass region. The Jungfrau syncline was also crossed significantly deeper by the new Lötschberg railway tunnel that links Raron in the Rhonetal to the south with Fruttigen in the Kandertal to the north (Kellerhals \& Isler 1998, and HansJakob Ziegler and Alfred Isler, BLS Alptransit AG, personal communication). An attempt to synthesize the structural data along the present section through the Aar massif and Penninic nappes to the south was made by Steck in 1984 (Fig. 3). The structure of the Jungfrau syncline is not cylindrical; the number of units composed of basement with their Mesozoic sediment cover in an overturned position varies. The number is for example different on the western (Fig. 4) and eastern side (Fig. 5) of the Inner Faflertal. This study focusses on the excellent and representative outcrops exposed at altitudes between 2300 and $2700 \mathrm{~m}$ on the left (eastern) side of the Inner Faflertal (Plate 1 and Fig. 5).

442 T. Krayenbuhl \& A. Steck 


\section{Stratigraphy}

We distinguish on the eastern (left) side of the Inner Faflertal, from bottom to top (NW to SE, Plate 1 and Fig. 5):

- the Gastern basement, its Permian paleosoil and isolated remnants of its Triassic sedimentary cover;
- two slices of Gastern granite gneiss, with their Mesozoic sedimentary cover in an overturned stratigraphic position (Units I and II);

- the overturned lower limb of the Tschingelhorn gneiss anticline, part of the Aar massif, with lenses of its strongly extended Mesozoic sedimentary cover.

SE

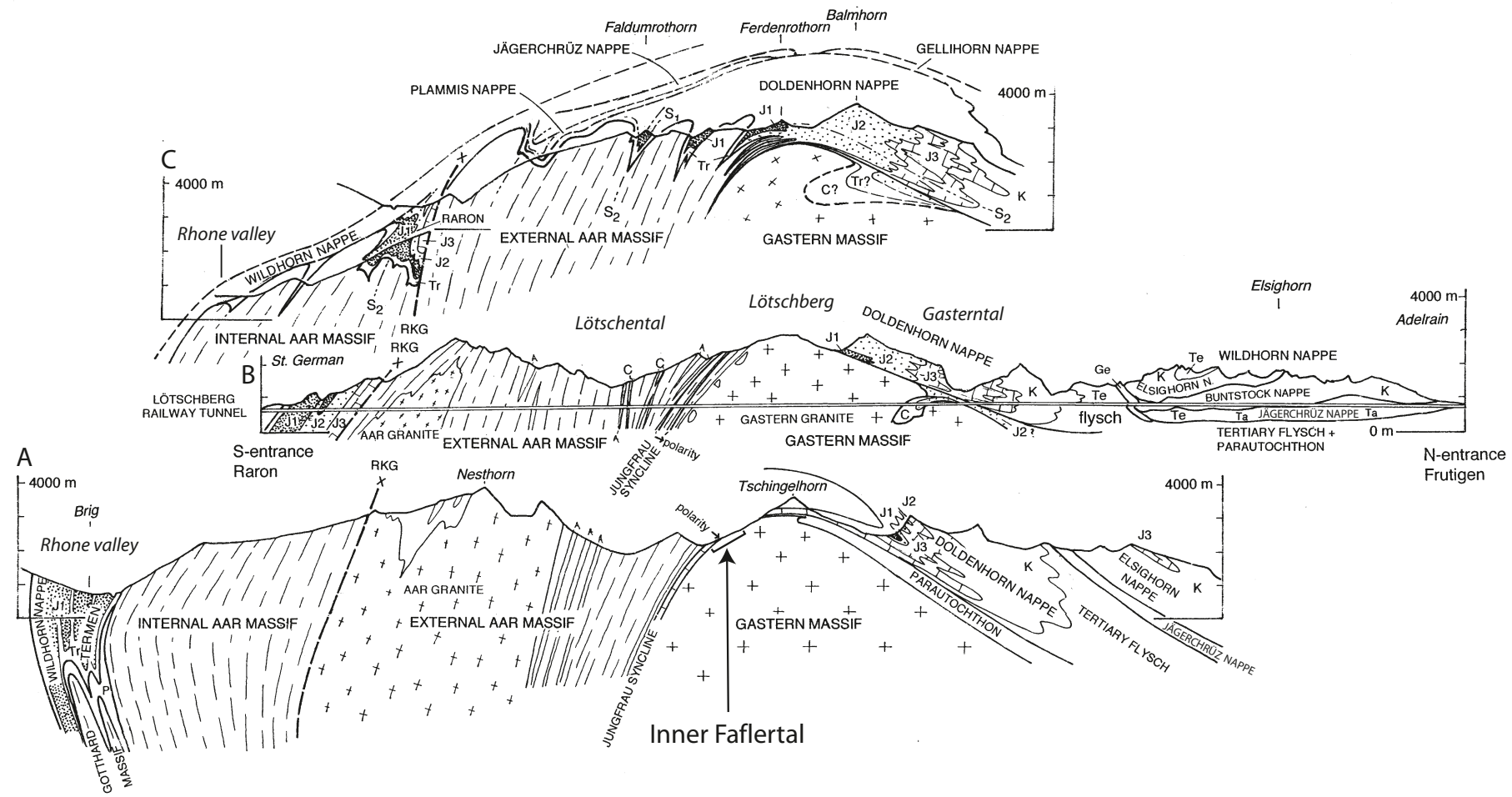

Fig. 2. Three geological cross-sections (A, B and C on Fig. 1) through the western Aar and Gastern massifs, sections A and C modified after Steck et al. (2001); section B of the new Lötschberg railway tunnel (Hans-Jakob Ziegler and Alfred Isler, BLS AlpTransit AG, personal communication). On these three sections the reader is looking parallel to the SW-plunge direction of the Aar and Gastern massifs, with the NW to the right and the SE to the left. This orientation is opposite to the NW (left) - SE (right) geological sections in the other Figs. in this paper. Key: A = amphibolite, C = Carboniferous, Ge = Gellihorn nappe, J1 = Liassic, $\mathrm{J} 2=$ Dogger, J3 = Late Jurassic, $\mathrm{K}=$ Cretaceous, $\mathrm{RKG}=$ Jurassic Rote Kuh - Gampel normal fault, $\mathrm{Ta}=$ Taveyanne flysch, $\mathrm{Te}=\mathrm{Tertiary}$ flysch, $\mathrm{Tr}=\mathrm{Triassic}$.

Table 1. Alpine tectonic units of the studied transect through the Helvetic domain, modified after Steck et al. (1999).

NW

\begin{tabular}{|c|c|c|c|c|c|c|}
\hline$\underbrace{\frac{\alpha}{1}}_{0}$ & $\begin{array}{c}\text { Tertiary } \\
\text { flysch } \\
\text { parautochthon }\end{array}$ & Doldenhorn & $\begin{array}{c}\text { Gellihorn } \\
\text { Plammis } \\
\text { Raron }\end{array}$ & $\begin{array}{c}\text { Jägerchrüz } \\
\text { Heidnischbiel }\end{array}$ & $\begin{array}{c}\text { Elsighorn } \\
\text { Buntstock } \\
\text { Termen }\end{array}$ & $\begin{array}{l}E \\
0 \\
\frac{0}{0} \\
0 \\
3\end{array}$ \\
\hline$\sum_{\substack{1 \\
\infty}}^{\substack{n \\
\infty}}$ & Gastern massif & External Aar massif & \multicolumn{2}{|c|}{ Internal Aar massif } & \multicolumn{2}{|c|}{ Gotthard massif } \\
\hline
\end{tabular}




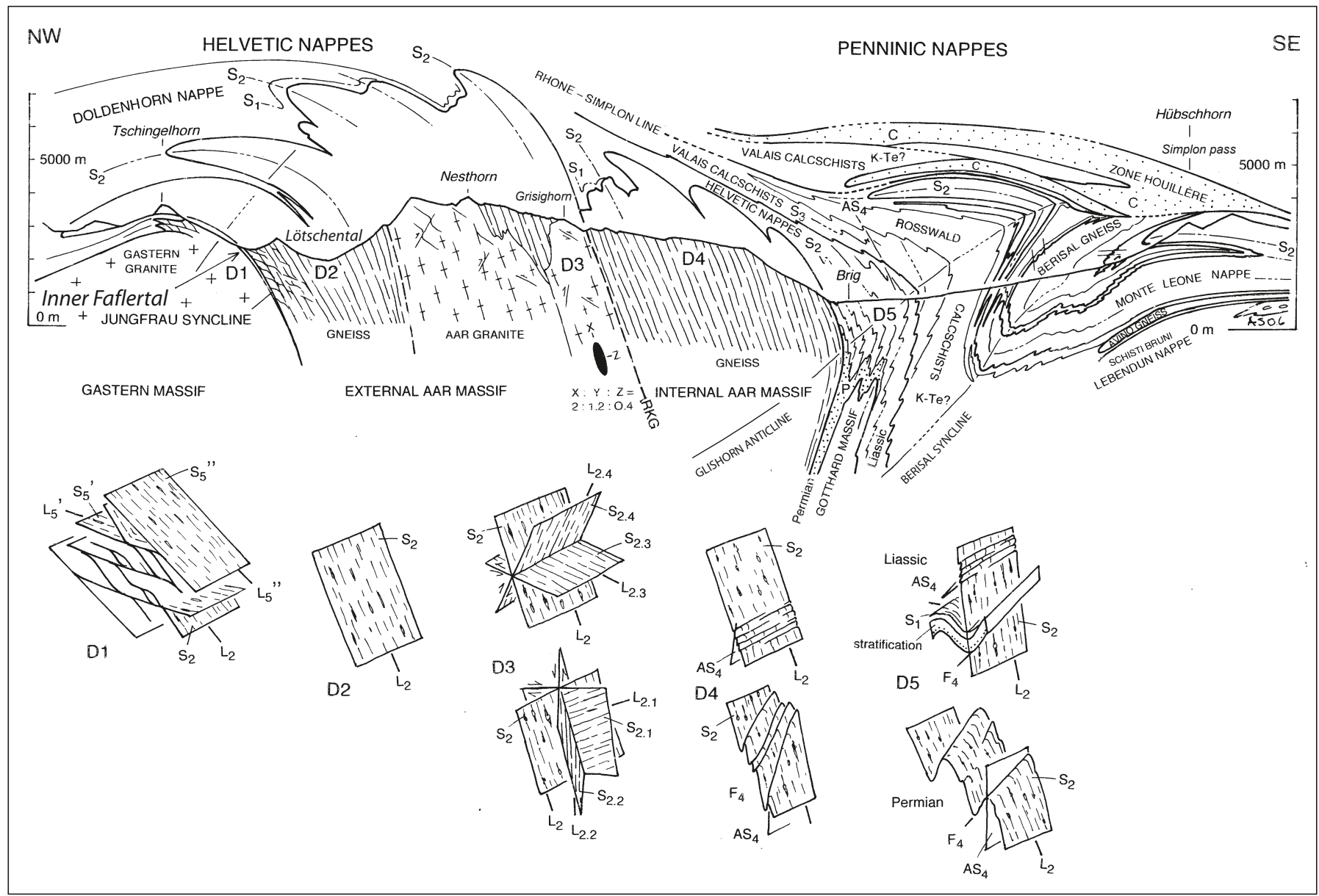

Fig. 3. The Alpine structures of the Tschingelhorn - Brig - Hübschhorn transect through the Helvetic and frontal Lower Penninic units, modified after Steck (1984).

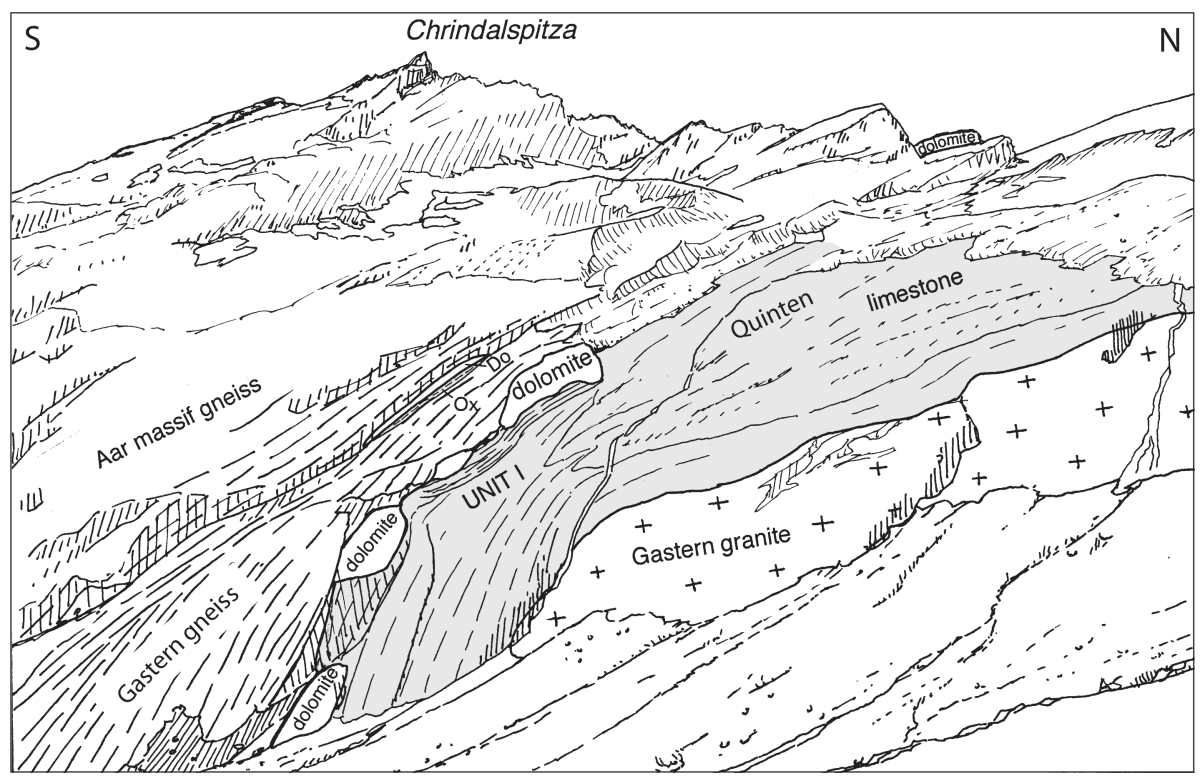

Fig. 4. View of the right (western) side of the upper Inner Faflertal with, from bottom to the top, three units forming the Jungfrau syncline structure: the Gastern granite in its normal position, and the Unit I and the Aar massif gneiss in an overturned position. Note that the competence of the Triassic dolomite boudins was higher than the Gastern and Aar massif gneiss and much higher than the Quinten marble.

444 T. Krayenbuhl \& A. Steck 


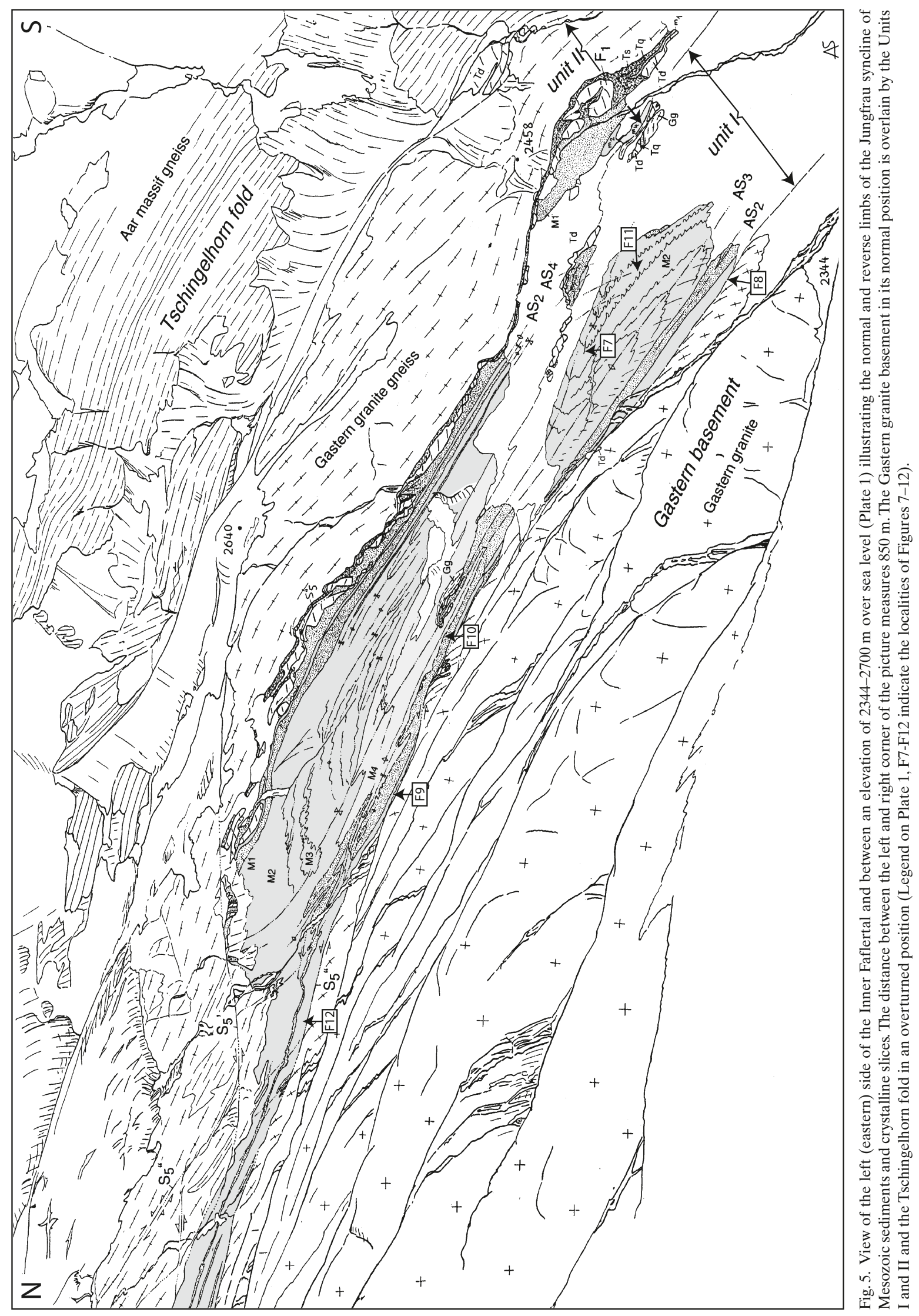


The Triassic to Jurassic stratigraphic columns for the four units are given on Fig. 6. For comparison, the complete stratigraphic column of the Doldenhorn nappe, composed of Triassic to Tertiary sediments (Krebs 1925; Lugeon 1914-1918; Herb \& Masson in Masson et al. 1980; Trümpy 1980; Loup 1992), is also shown.

The Gastern granite is a biotite-granodiorite, intrusive into pinite and cordierite migmatites of the Lauterbrunnen crystalline (Rutishauser \& Hügi 1978). Zircons of the Gastern granite have been dated at $303 \pm 4$ Ma by Schaltegger (1993) using the $\mathrm{U}-\mathrm{Pb}$ method. The surface of the Gastern granite is affected by a green and red coloured zone of weathering, attributed to the Permian (Hügi et al. 1988), and locally transformed to a depth of 1-2 meters into a brown coloured granitic arenite, with decimetric to metric brown concretions of ferruginous dolomite, testifying to the preservation of a Permian paleosol. Spectacular outcrops of this paleosol are exposed at an altitude of $2520 \mathrm{~m}$ in the Inner Faflertal and also in the Lötschberg area. Above this Permian paleosol, the sedimentary cover is restricted to autochthonous Triassic slate and dolomite in the Lötschental. The younger Jurassic-Tertiary sediments are believed to have been detached and moved northwards; they are interpreted to occur farther north at Stechelberg, in the upper Lauterbrunnental, on the western slope of the Silberhorn (Collet \& Paréjas 1931; Herb in Masson et al. 1980). At this locality, Upper Jurassic to Cretaceous sediments in a normal succession occur as imbricated slices between the autochthonous Mesozoic-Cenozoic sediments of the Gastern massif and the inverted limb of the Doldenhorn fold nappe.

In the present study area, the Jungfrau syncline is composed of two slices of Gastern granite gneiss, each with their Mesozoic sedimentary cover in an overturned stratigraphic position (Units I and II);

Unit I consists of Triassic slate and carbonates overlain by Late Jurassic limestone (Quinten limestone). The Triassic sequence

\section{A: Autochthon of B: Unit I \\ C: Unit II east \\ D: Unit II west Gastern massif

B: Unt I \\ E: Doldenhorn nappe after Krebs, 1925}

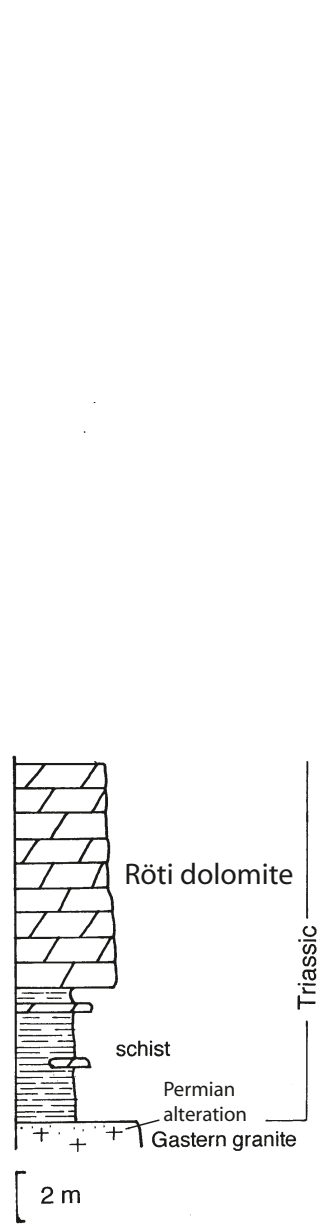

Late Jurassic
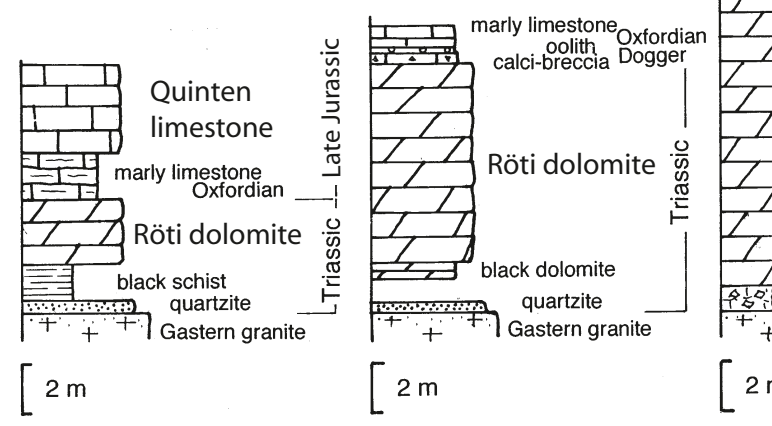

Fig. 6. Stratigraphic columns of the tectonic units that compose the Jungfrau syncline.

446 T. Krayenbuhl \& A. Steck 
is an up to $10 \mathrm{~m}$ thick, condensed sequence of siliciclastic sediments, carbonates and evaporites deposited during the Middle - Late Triassic on a shallow marine platform environment on the European continental margin (Frey 1968, 1969). They were transformed to quartzite, slate, dolomite and anhydrite through low grade metamorphism. Anhydrite rocks and anhydrite-bearing dolomites are exposed in the Lötschberg railway tunnel. They are altered at the surface into a cellular dolomite breccia, known as cargneule (in France) and cornieule or Rauhwacke (in Switzerland); good examples occur on the western flank of the Inner Faflertal. The Early and Middle Jurassic marks a long period of non-deposition/erosion in Unit I. Sedimentation resumes in the Late Jurassic with shallow marine marly greenish-grey limestones and massive light-grey, partly dolomitic limestones attributed to the Oxfordian and the Quinten limestone respectively. These limestones are partly transformed into marbles.

Unit II is similar to Unit I, except that a member composed of sandy limestone and oolitic limestone attributed to the Middle Jurassic separates the Triassic from the Late Jurassic member.

Cretaceous and Tertiary sediments are missing in both units. It is supposed that these higher sequences were detached during an early phase of top-to-the-NW thrusting at the base of the higher Helvetic and Penninic nappe stack, preceding the formation of the Aar massif basement gneiss folds.

The stratigraphic gaps in the sedimentary cover of the Gastern massif and Units I and II testify to the presence of a paleo-relief controlling the sedimentation to the north of the Doldenhorn basin (the future external Aar massif, Figs. 1 and 2) during the Early to Middle Jurassic. The half-graben geometry of the Doldenhorn basin is described in the next section.

\section{Tectonic structures}

\section{The Mesozoic Doldenhorn half-graben basin and its Alpine} folding ( $F_{1}$ folds and $S_{1}$ schistosity)

The number of tectonic units that compose the Jungfrau syncline is variable, but their overturned stratigraphic polarity is a constant feature in all studied outcrops between the Inner Faflertal to the east and the Lötschenpass to the west. It is also observed in the new Lötschberg railway tunnel (Figs. 1 and 2; Hans-Jakob Ziegler and Alfred Isler, BLS - Alptransit AG, personal communication). The Gastern massif preserved its original normal position, whereas the stratigraphic polarity was uniformly overturned in the Units I and II and in the lower limb of the northern gneiss fold of the Aarmassif, the Tschingelhorn fold (Figs. 1, 3 and 5, and Plate 1). Collet \& Parejas (1931), describing the inverted stratigraphic succession, already proposed that this rotation could only happen by folding. In their model, the Gastern massif forms the lower normal limb of the Jungfrau syncline, and the Units I and II and the Tschingelhorn unit an upper overturned limb linking to the Doldenhorn fold nappe.
As indicated later, we suggest in our model that the Units I and II evolved from a half-graben geometry with en-echelon discontinuous SE-dipping Jurassic normal faults at the margin of the Doldenhorn basin, with the upper units apparently deposited farther away from a Gastern basement paleo-high. We propose that the fault blocks were deformed in a ductile regime in a top-to-the NW-directed shear zone, leading to the non-cylindrical geometry of the Jungfrau syncline. Such overturned half-graben limbs of metric to decametric dimensions are also observed at elevations of 2500 and $2570 \mathrm{~m}$ at the limit between the Gastern basement and Unit I (Plate 1). $F_{1}$ folds and a penetrative $S_{1}$ schistosity were developed during this first phase of Alpine deformation. They are difficult to recognize, as they have been pervasively overprinted by subsequent deformation stages. Veins parallel to $S_{1}$ with quartz-calcite fibres also developed during the first phase of Alpine deformation and are observed in the fold hinges of later folds (Figs. 7 and $8) . F_{1}$ folds are very rare. An example is exposed $50 \mathrm{~m}$ to the $\mathrm{S}$ and below the point $2458 \mathrm{~m}$ on the structural map (Plate 1; Swiss coordinates: 632.930/139.565) and in the outcrop view of Fig. 5. The axial surface of that fold has a more shallow dip than that of the Mesozoic zone and of the later folds, pointing to the fact that the Jungfrau syncline has probably developed as a true $F_{1}$ syncline. Only the upper part of the Gastern granite and gneiss is affected by this deformation. A SE-dipping schistosity penetrates into the Gastern basement surface at an acute and steeper angle and only a few centimetres to decimetres (Fig. 9). The Gastern granite preserved its pre-Alpine magmatic structure in deeper parts. The formation of the superficial NW-verging schistosity in the Gastern granite was contemporaneous with the successive development of the three $\left(\mathrm{S}_{1}-\mathrm{S}_{3}\right)$ schistosities and crenulation cleavages in the higher units.

\section{Main second schistosity $S_{2}, S E$-plunging stretching lineation $L_{2}$, and $F_{2}$ folds}

The Jungfrau syncline was overprinted during a second phase of Alpine deformation by a second penetrative schistosity $\mathrm{S}_{2}$, characterised by a SE-plunging stretching lineation $\mathrm{L}_{2}$ and isoclinal $\mathrm{NW}$-verging $\mathrm{F}_{2}$ folds. The $\mathrm{F}_{2}$ fold axes are mostly rotated parallel to the SE-dipping $\mathrm{L}_{2}$ stretching direction. The pre-existing $\mathrm{S}_{1}$ schistosity was transposed in the $x y$-plane of the second schistosity and the existence of the first schistosity can only be recognised in $F_{2}$ fold hinges. The $S_{2}$ schistosity appears as a spaced axial plane crenulation cleavage in $\mathrm{F}_{2}$ fold hinges (Figs. 8 and 9). The main $\mathrm{NW}$-verging $\mathrm{S}_{2}$ schistosity is steeper and forms an acute angle of $0-10^{\circ}$ with the stratification and also with the boundaries between the Gastern basement, the Units I and II and the Tschingelhorn fold. This means that the NW-verging $\mathrm{S}_{2}$ schistosity has the opposite vergence to that expected for its position on the overturned $F_{1}$ fold limb of the Doldenhorn anticline and crosscuts the flatter SE-dipping Jungfrau syncline $\left(\mathrm{F}_{1}\right)$ at an acute angle (Fig. 9). It cannot therefore be the axial plane schistosity to these folds but must be a younger, overprinting and crosscutting $\left(\mathrm{S}_{2}\right)$ schistosity. 


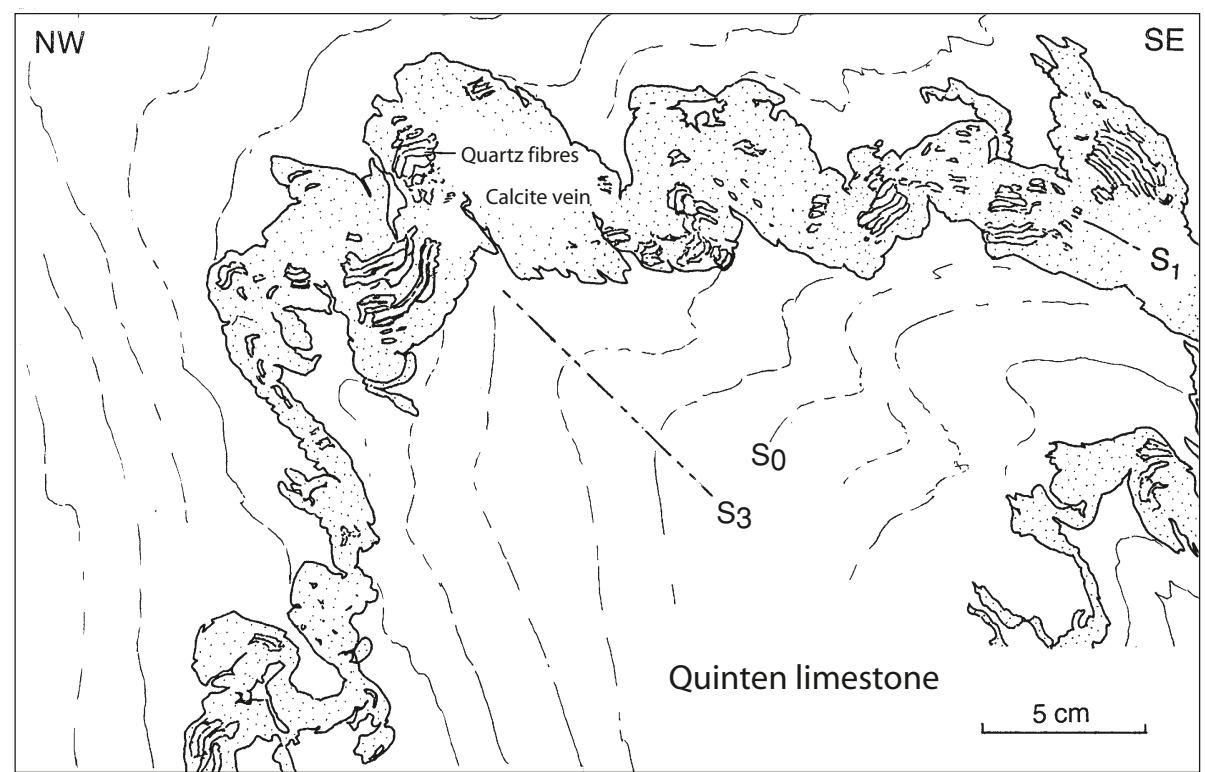

Fig. 7. Calcite vein in the Quinten limestone with quartz fibres oriented parallel to the stretching lineation $\mathrm{L}_{1}$ on the first schistosity $\mathrm{S}_{1}$, which is deformed by $\mathrm{F}_{3}$ folds (axial surface marked $\mathrm{S}_{3}$ ). $\mathrm{S}_{0}=$ stratification. Inner Faflertal, elevation: $2370 \mathrm{~m}$ on Plate 1.
$N W$-verging $F_{3}$ folds and their axial surface cleavage $\mathrm{AS}_{3}$ and $S E$-plunging stretching lineation $L_{3}$

A third phase of Alpine deformation produced spectacular $\mathrm{NW}$-verging $\mathrm{F}_{3}$ folds with an axial surface crenulation cleavage $\left(\mathrm{AS}_{3}\right)$ and a third SE-plunging stretching lineation $\left(\mathrm{L}_{3}\right.$, see Figs. 5, 8, 9, 10 and 11). The orientation of the $F_{3}$ fold axis is more variable, but a transposition in the main SE-plunging direction of $\mathrm{L}_{3}$ is also observed. Sheath folds related to strongly stretched $\mathrm{F}_{2}-\mathrm{F}_{3}$ fold interference pattern are locally developed in the very ductile Late Jurassic Quinten limestone (at an elevation of $2540 \mathrm{~m}$ in Unit I, see Plate 1).
$N W$-vergent $F_{4}$ folds, development of two sets of top-to-the-NW directed shear zones $S_{5^{\prime}}$ and $S_{5^{\prime \prime}}$ and the back folding of the Gastern and Aar massifs

The $\mathrm{F}_{3}$ fold hinges are locally affected by a fourth generation of NW-verging folds, $\mathrm{F}_{4}$, testifying to a continuation of the NWdirected rotational deformation (Fig. 5). A later deformation of the $\mathrm{F}_{3}$ folds may also be produced by a flattening, with a resulting rotation of the $\mathrm{F}_{3}$ fold hinges (Fig. 11). The late period of deformation is characterised by two sets of top-to-the-NW directed discrete shear zones, the flatter $S_{5^{\prime}}$ and steeper $S_{5^{\prime \prime}}$ planes, with their $\mathrm{SE}$-dipping $\mathrm{L}_{5^{\prime}}$ and $\mathrm{L}_{5^{\prime \prime}}$ stretching lineations,

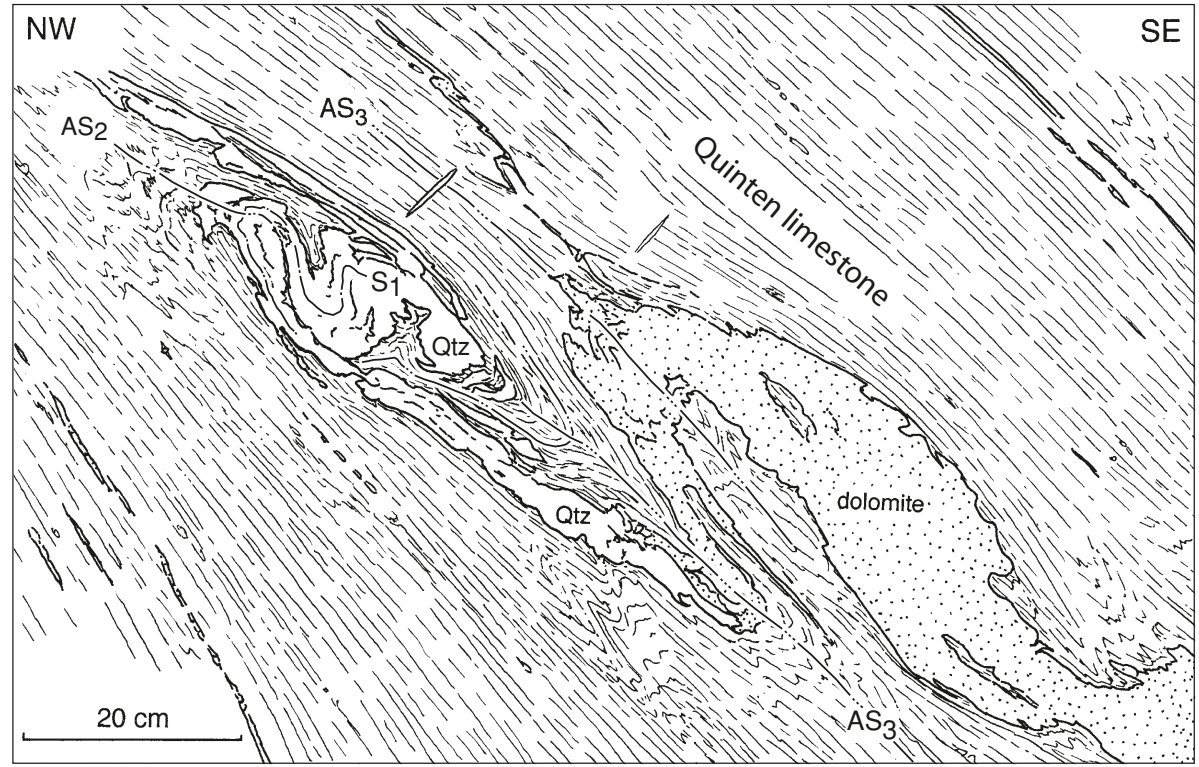

Fig. 8. Foliated Quinten limestone with a stratiform dolomite layer and a $\mathrm{S}_{1}$-parallel quartz vein, deformed by second and third folds, axial surface traces marked $\mathrm{AS}_{2}$ and $\mathrm{AS}_{3}$. Inner Faflertal, elevation: $2370 \mathrm{~m}$.

448 T. Krayenbuhl \& A. Steck 


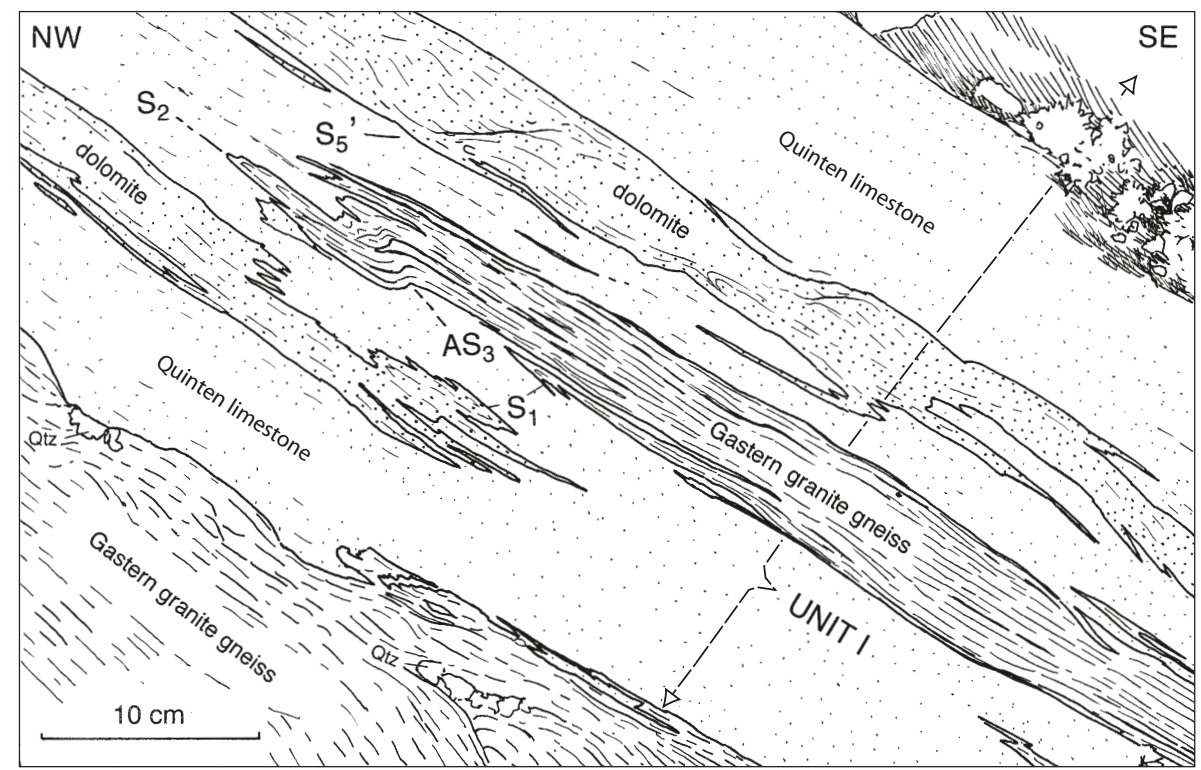

Fig. 9. Contact between the superficially altered (Permian) and Alpine foliated Gastern granite gneiss and the strongly deformed Quinten limestone with dolomite layers of the inverted Unit I. The dominant NW-verging $S_{2}$ folds and $S_{2}$ schistosity deform an early schistosity $S_{1}$ and are affected by a third fold and top-to-the-NW $\mathrm{S}_{5}$, shear bands. Inner Faflertal, elevation: $2550 \mathrm{~m}$. that may be of a similar age (Plate 1, Figs. 5, 12, 13 and 14). Such shear zones are named shear band cleavages by Platt and Vissers (1980) and Passchier \& Trouw (1996), or also asymmetric extensional crenulation cleavage by Platt and Vissers (1980). They are similar to the $S / C$ fabrics of Berthé et al. (1979). These shear zones developed during a late phase deformation of the pre-existing $\mathrm{S}_{1}-\mathrm{S}_{3}$ mylonites and reflect cooler and more brittle conditions during that phase. The structural map (Plate 1) and Figs. 5 and 15 show that these late shear bands produced an asymmetric foliation boudinage of the crystalline slice of unit II inside the Jungfrau syncline. Asymmetric foliation boudinage is a term introduced by Platt and Vissers (1980) for similar struc- tures. The main foliation is defined in the gneiss of the Aar massif by the $x y$-plane of the strain ellipsoid (Fig. 3). This foliation was locally overprinted by late top-to-the-NW directed shear zones. Pre-existing structures such as some major $\mathrm{S}_{2}$ mylonite zones, the northern contact of the Aar granite and the Jurassic Rote Kuh Gampel normal fault (RKG on Figs. 2 and 3; Dolivo 1982) were reactivated in a late phase by reverse faulting. Some late shear zones contain fault gouges and may represent active faults (Steck 1968). It is important to remember that these topto-the-NW shear movements are late deformational structures and do not represent the initial thrust faults. The up-doming of the Gastern massif together with the back-folding of the south-

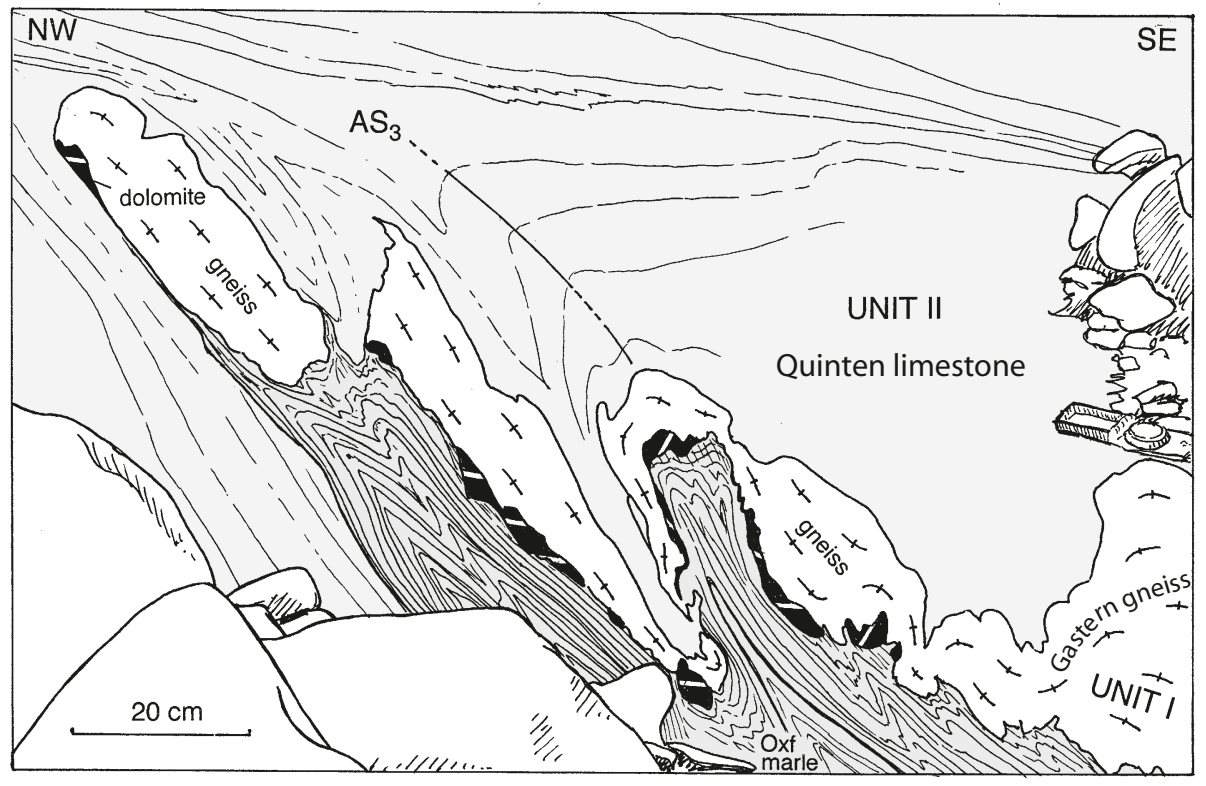

Fig. 10. Contact between the overturned Units I and II, deformed by third NW-verging $\mathrm{F}_{3}$ folds. Recognise the composite $S_{1}-S_{2}$ foliation in the Oxfordian marly limestone (Oxf marl). Inner Faflertal, elevation: $2480 \mathrm{~m}$. 


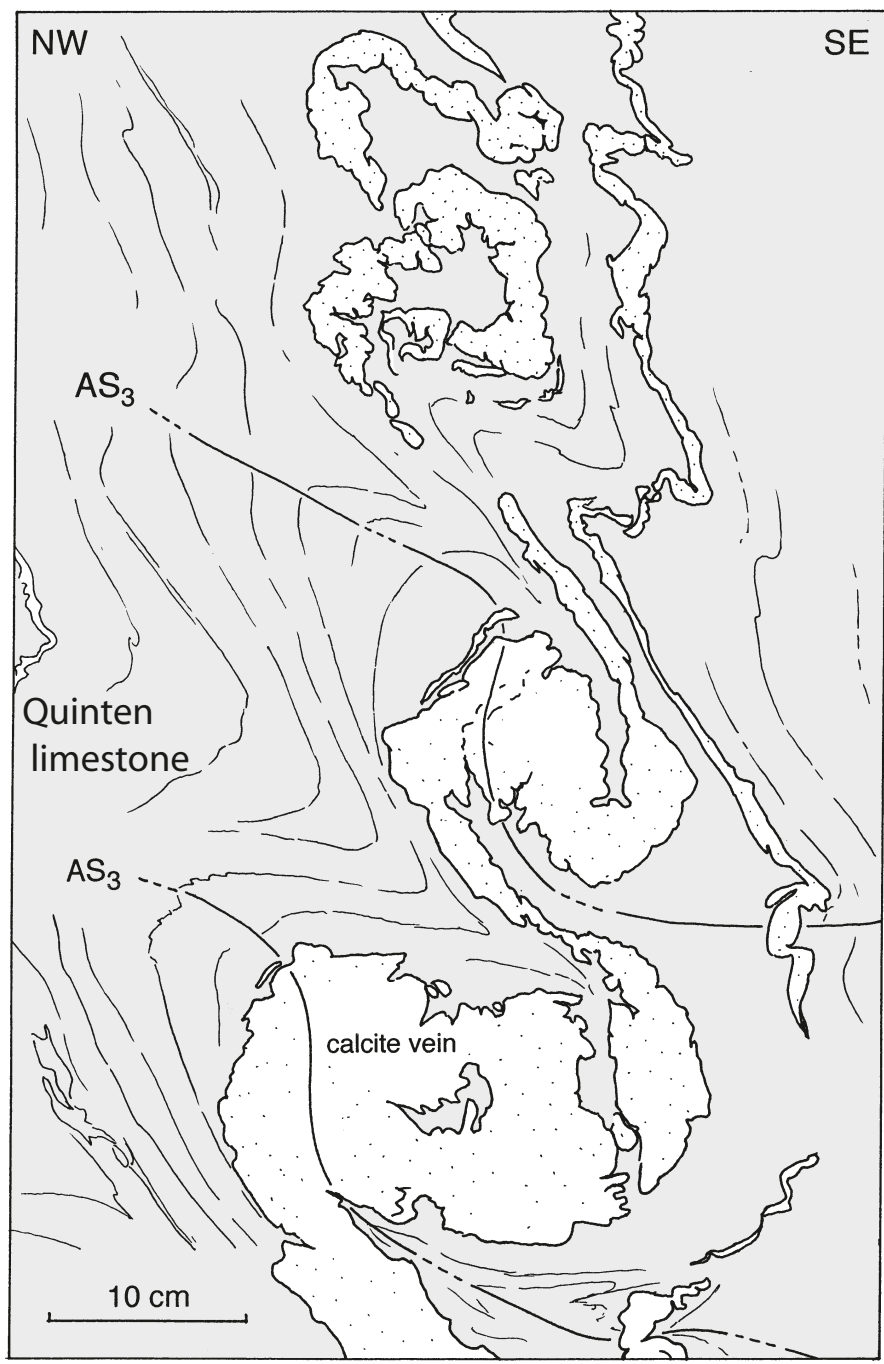

Fig. 11. Quinten limestone with first phase $S_{1}$ calcite veins folded by $F_{3}$ folds; the axial surface $\mathrm{AS}_{3}$ is folded or flattened by a later, fourth phase of deformation. Inner Faflertal, elevation 2410 m.

ern Aar massif and the formation of the Glishorn anticline and Berisal syncline in the Penninic Monte Leone and Pontis-Berisal nappes were formed during a late phase of SE-verging backfolding (Fig. 3). This backfolding is likely to be related to the phase of high exhumation rates of $3 \mathrm{~km} / \mathrm{Ma}$ of the western Aar massif at $6 \pm 0.5 \mathrm{Ma}$ ago, revealed by zircon $(\mathrm{U}-\mathrm{Th}) / \mathrm{He}$ thermochronology (Aramowicz et al. 2007). It has been interpreted as a conjugate structure to the NW-directed thrusting of the Jura range some 9-3 Ma ago (Steck, 1990; Steck et al., 2001).

\section{Estimation of strain and displacements}

The evolution of the relative position of the Units I and II and the Tschingelhorn fold leads to the model of Figs. 15 and 16, in which simple shear forms the dominant mechanism of deformation responsible for the rotation of the structures within the overturned lower limb of the Doldenhorn nappe. We attempt

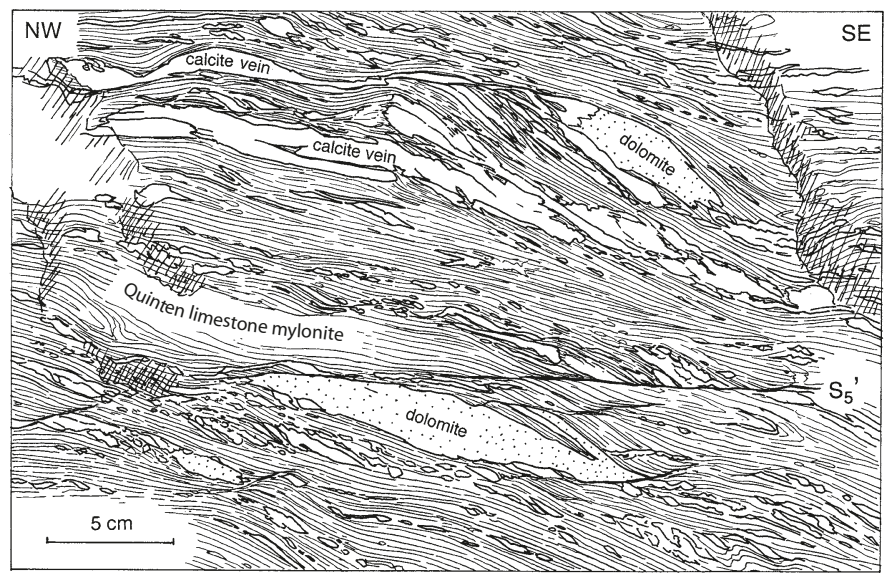

Fig. 12. Strong $S_{1}-S_{3}$ composite foliation and stretched Quinten limestone with stratiform dolomite boudins and concordant calcite veins $\left(\mathrm{S}_{1}\right.$ ? $)$ that were affected at a late stage by top-to-the-NW extensional shear bands $\mathrm{S}_{5^{\prime}}$. Inner Faflertal, elevation $2580 \mathrm{~m}$.

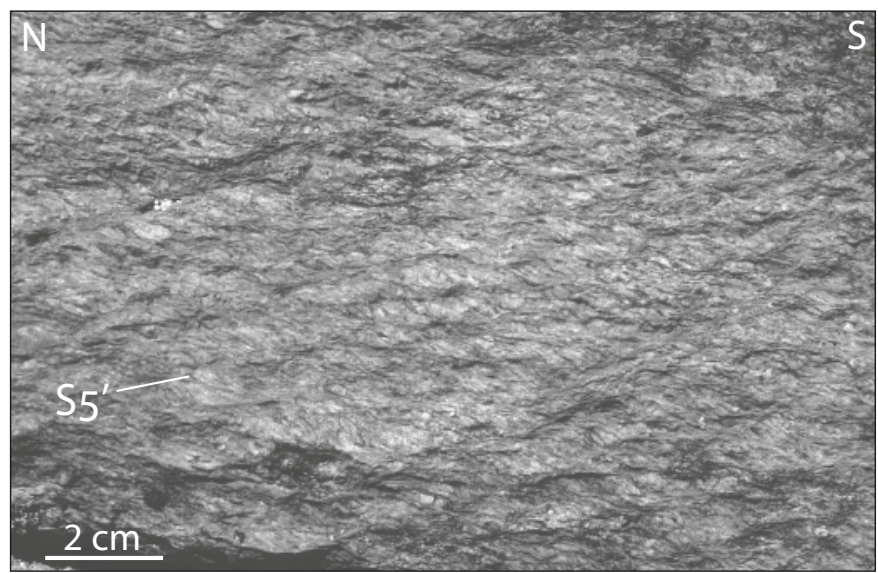

Fig. 13. Shear bands $S_{5}$ in Gastern granite gneiss from Tellispitza (Äusseres Faflertal).

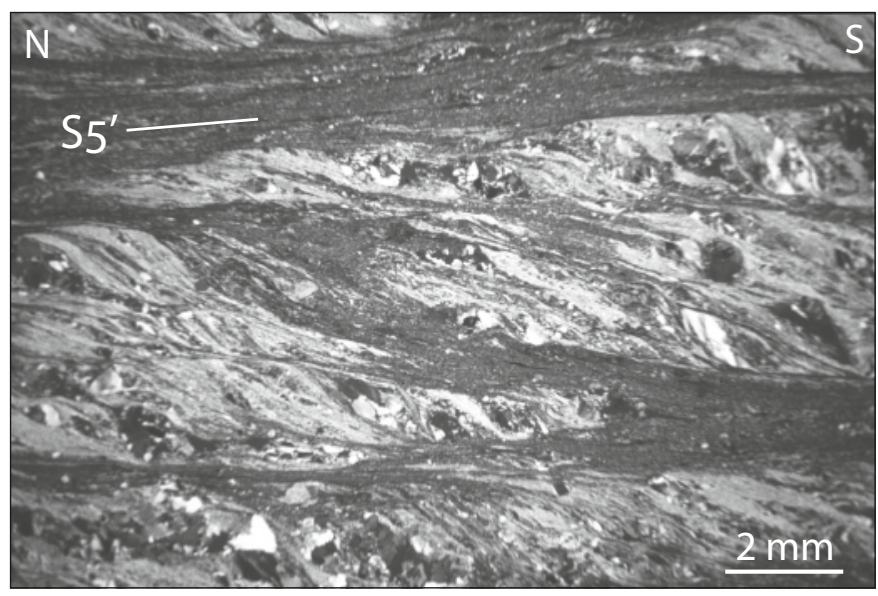

Fig. 14. Thin section (crossed nicols) of shear bands in Gastern granite gneiss from Tellispitza (Äusseres Faflertal). 
PREALPINE SITUATION

Liassic-Cretaceous

normal faults

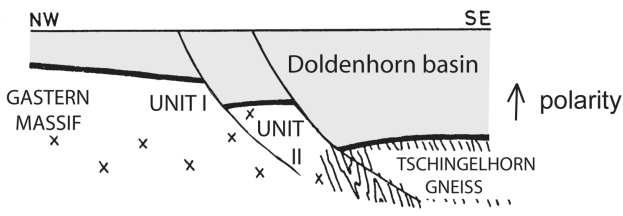

\section{ALPINE TECTONICS}

FIRST DEFORMATION: rotation by simple shear of units I and II and the

inverted limb of the Tschingelhorn fold $F_{1}$ and schistosity $S_{1}$
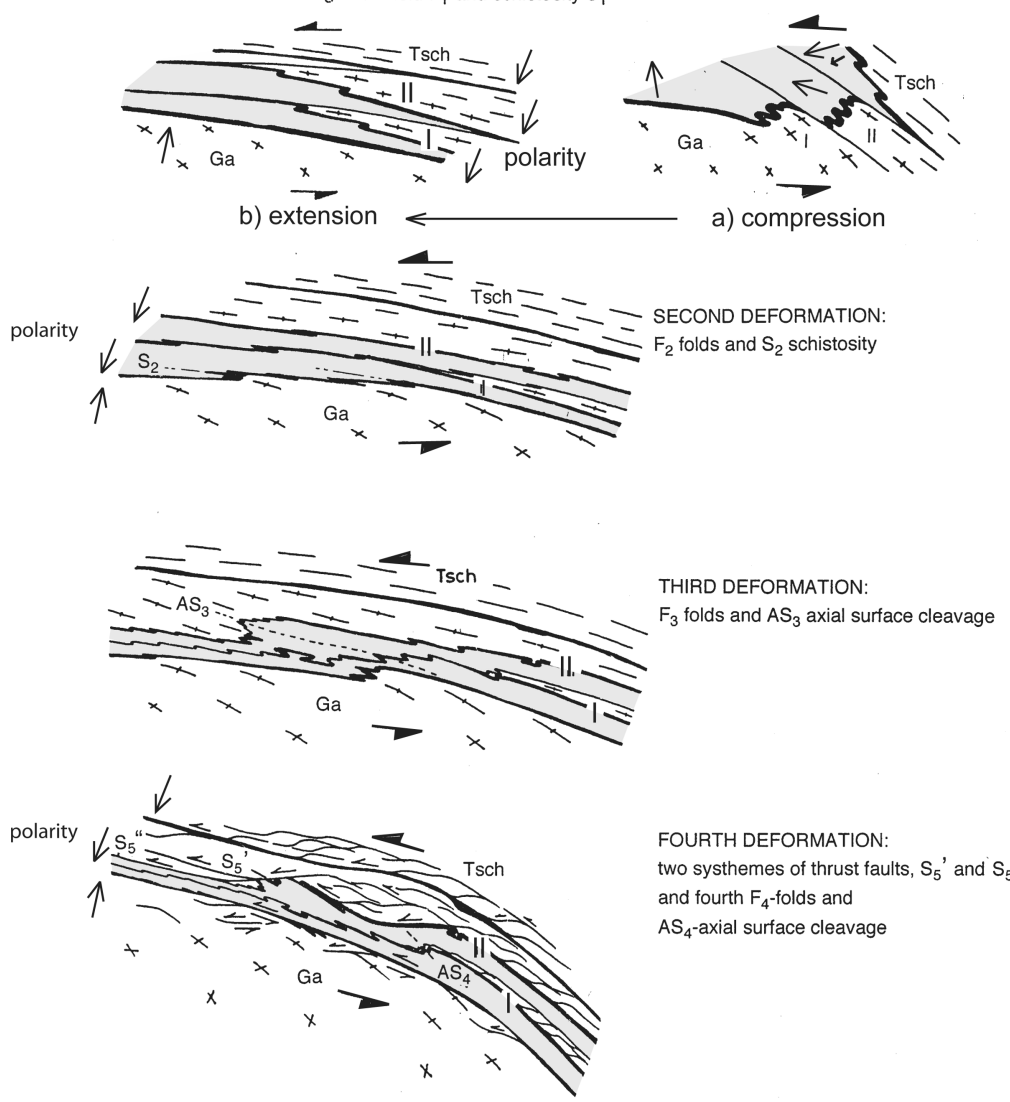

FOURTH DEFORMATION

two systhemes of thrust faults, $\mathrm{S}_{5}{ }^{\prime}$ and $\mathrm{S}_{5}{ }^{\prime \prime}$

and fourth $\mathrm{F}_{4}$-folds and

$\mathrm{AS}_{4}$-axial surface cleavage

here to quantify the strain and displacement in the Jungfrau syncline according to the methods discussed by Ramsay (1967, 1980).

The rotation of any passive planar marker by simple shear is given by the equation:

$\operatorname{cotg} \alpha^{\prime}-\operatorname{cotg} \alpha=\gamma=\operatorname{tg} \varphi$

where $\alpha$ is the angle of its trace on the $x z$-plane with the $x$ direction ( $x=$ direction of simple shear) before deformation and $\alpha^{\prime}$ is the angle of that trace with the $x$-direction after deformation. The parameters $\gamma$ and $\varphi$ represent the shear strain and the angular shear strain respectively. We assume an angle of rotation $\alpha=160^{\circ}$ for the initially horizontal stratification and a final angle $\alpha^{\prime}=2^{\circ}$ with the $x$-direction of simple shear on a supposed $20^{\circ} \mathrm{SE}$-dipping $x y$-shear plane (Fig. 16). The resulting values are 31.4 for the shear strain $\gamma$ and $88^{\circ}$ for the angular shear strain $\varphi$; the axes of the finite deformation ellipsoid $\left(1+\mathrm{e}_{1}\right)$ and $\left(1+\mathrm{e}_{3}\right)$ are calculated as 31.43 and 0.03 respectively resulting in a ratio $\mathrm{R}\left(1+\mathrm{e}_{1} / 1+\mathrm{e}_{3}\right)$ of $\sim 1000$. It is evident that this calculation, based on a simple shear model and approximate values of $\alpha$ and $\alpha^{\prime}$, represents a coarse estimation. This intense deformation is concentrated in the overturned limb of the Doldenhorn fold nappe. The resulting geometry corresponds to a some hundred metre wide ductile shear zone, created by compression and folding. This contrasts with quantifications of deformation made elsewhere in the Aar massif. In the Aar granite gneiss folds of the Grisighorn (Fig. 3), measurements of the finite deformation ellipsoid on mafic inclusions indicate an axial ratio of $\mathrm{X}: \mathrm{Y}: \mathrm{Z}=2: 1.2: 0.4$ (Steck 1968,1984). Assuming that this ratio represents a mean value for the Aar massif gneiss strain, the Doldenhorn basin is likely to have been shortened in a NW-SE direction by about $60 \%$. 


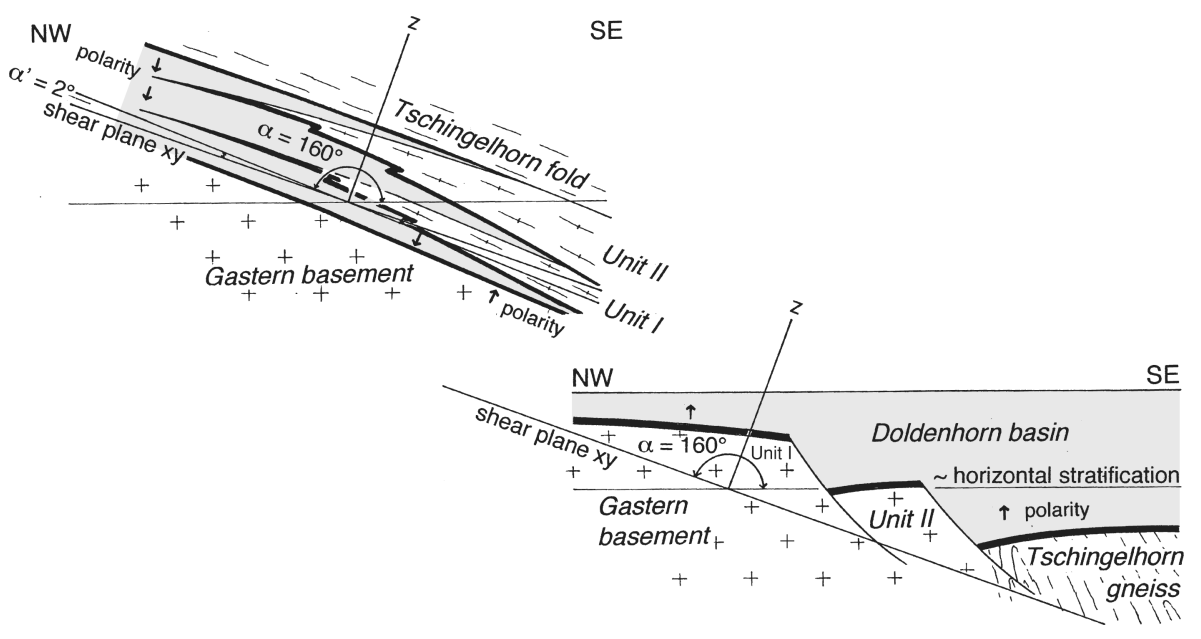

Fig. 16. A quantitative estimate of the deformation of the Jungfrau syncline by simple shear, after Ramsay $(1967,1980)$ based on a supposed $20^{\circ}$ SW-dip of the $x$-direction of the $x y$ shear plane, an angle of rotation $\alpha=160^{\circ}$ and a final angle $\alpha^{\prime}=2^{\circ}$. The resulting values are: 31.4 for the shear strain $\gamma, 88^{\circ}$ for the angular shear strain $\varphi$ and $\mathrm{R}=1+\mathrm{e}_{1} /$ $1+\mathrm{e}_{3}=31.43 / 0.03=\sim 1000$.

\section{Tertiary metamorphism and rock rheology}

The rheology of the marbles and gneisses forming the Jungfrau syncline was controlled by temperature and water pressure. It is assumed that the ductile deformation was related to peak metamorphic conditions. Frey and Wieland (1975) mapped the reaction-isograd for the reaction pyrophyllite $+\mathrm{Fe}$-chlorite $=\mathrm{Fe}$-chloritoid + quartz $+\mathrm{H}_{2} 0$ in Al-rich Liassic marls and marly limestones of the Helvetic nappes. The isograd is situated at the western end of the Jungfrau syncline, indicating a temperature of approximately $300{ }^{\circ} \mathrm{C}$ for this region (Bucher and Frey, 1994). A similar temperature of $300{ }^{\circ} \mathrm{C}$ and a pressure of 2-3 kb were estimated by Frank (1983) for the frontal Doldenhorn nappe. These data are confirmed by an illite crystallinity study by Burkhard (1988) showing that the Doldenhorn nappe, with the exception of its frontal anchizonal hinge, has epizonal crystallinity values of $<0.25^{\circ} \Delta 2 \theta \mathrm{CuK} \alpha$ (Scherrer width). Another indicator for the degree of metamorphism is the first occurrence of Alpine biotite in granitic gneisses of the Aar massif, coexisting with chlorite over some kilometres and replacing the latter in the southern Aar massif (Steck \& Burri 1971). The passage from the chlorite zone in the Gastern massif to the biotite zone in the Aar massif is gradual. A systematic calcite-dolomite solvus temperature study of the Quinten limestone mylonites of the basal Doldenhorn thrust by Herwegh \& Pfiffner (2005) reveal a continuous variation over a distance of $10 \mathrm{~km}$ of metamorphic peak temperatures between $385 \pm 25^{\circ} \mathrm{C}$ in the Jungfrau syncline to the SE and $348 \pm 25^{\circ} \mathrm{C}$ below the nappe front to the NW. These authors deduce a geothermal gradient of over $36^{\circ} \mathrm{C} / \mathrm{km}$ for peak metamorphic conditions and retrograde exhumation at $9 \mathrm{Ma}$. This temperature gradient is much higher than the metamorphic field gradient of $25^{\circ} \mathrm{C} / \mathrm{km}$ observed for the Tertiary metamorphic event in the Aar massif - Ossola valley transect (Frank 1983). The calculated overburden thickness of about $10 \mathrm{~km}$ would have been composed of the higher Helvetic and the Penninic (Prealps) nappes. The transition from brittle to ductile behaviour for wet quartz is supposed to occur at temperatures around $300^{\circ} \mathrm{C}$ (Voll 1976;
Stipp et al. 2002). The granites and gneisses, composed of over $30 \mathrm{vol} \%$ of quartz, were thus capable of viscous flow under the peak metamorphic conditions.

The timing of the formation of the Doldenhorn nappe is constrained by radiometric and stratigraphic ages. The deformation must be younger than the $33 \pm 0.2$ Ma Taveyanne andesite bearing graywackes of the higher Gellihorn and Jägerchrüz nappes (Ta on Fig. 2; Ruffini et al. 1995, 1997) and older than the Gastern and Aar massif backfolding that occurred at about 6 Ma (Steck et al. 1979 ; Steck 1984; Burkhard 1990; Steck \& Hunziker 1994; Aramowicz 2007). Kirschner et al. (1995, 1996, 2003) propose a time span between 32 and $15 \mathrm{Ma}$.

\section{Tectonic model}

The rise of temperature above $300{ }^{\circ} \mathrm{C}$ plays a predominant role in the ductile formation of the Jungfrau syncline in the model presented in Fig. 15. Propagation of the Alpine deformation towards the northwest led to the extrusion of the Mesozoic Doldenhorn basin sediments squeezed between the rigid Gastern/Lauterbrunnen basement high and the higher Helvetic and Penninic nappes (e.g. Trümpy 1980; Steck 1984; Burkhard 1988). The Doldenhorn basin fill was pushed towards the northwest in an early phase of NW-directed thrusting, a movement recorded in our study area by the formation of a first schistosity $\mathrm{S}_{1}$ with its SE-dipping stretching lineation $\mathrm{L}_{1}$. This first schistosity may be observed in the Mesozoic sediments of the Feselalp and the Faldumrothorn synclines, situated in the southern part of the Doldenhorn nappe (Figs. 1,2 and 3; cf. Steck 1984, Fig. 5). Crustal thickening related to the emplacement of the higher Helvetic and the Penninic nappes led to a temperature increase of the Doldenhorn basin fill. Temperatures in excess of $300^{\circ} \mathrm{C}$ were reached below a more than $10 \mathrm{~km}$ thick orogenic lid, composed of the higher Helvetic and the Penninic (Prealps) nappes. At those temperatures, granites and quartz-rich gneisses became ductile. The Aar massif gneisses were flattened and the contact with the Mesozoic basin sediment cover folded (Figs. 2 and 3). The front of ductile deformation migrated from south-

452 T. Krayenbuhl \& A. Steck 
east to northwest through the Aar massif together with the progressive heating of the subducted crust. It reached the northern margin of the Mesozoic Doldenhorn half-graben basin, the future Jungfrau syncline, at a late stage of Alpine underthrusting. The elevated graben borders were deformed in a zone of topto-the-NW directed shear under high temperature conditions $\left(\sim 300{ }^{\circ} \mathrm{C}\right)$ and rotated to their overturned position by simple shear (Figs. 15 and 16). The pre-existing SE-dipping normal faults behaved during this deformation as passive markers and do not appear to have been reactivated by reverse-fault movements. The Jungfrau zone developed as a syncline between the more ductile Aar massif to the SE and the more competent Gastern basement high to the NW. The localisation of the Jungfrau syncline on the northern border of the Doldenhorn half graben basin is probably caused by the presence of a buttress formed by the Gastern basement high against which hot quartz-rich gneisses started to deform in a ductile manner due to elevated temperatures. An additional reason that favoured the development of the Tschingelhorn gneiss fold was probably the high amount of water, produced by the dehydration reactions of the Mesozoic marls during the Tertiary metamorphism, and the circulation of that water along pre-existing basement faults at the northern limit of the Doldenhorn sedimentary ba$\sin$. The Jungfrau syncline evolved in a zone of intense shear with the development of the main $\mathrm{S}_{2}$ schistosity and its associated SE-dipping $\mathrm{L}_{2}$ stretching lineation, and of $\mathrm{NW}$-verging $\mathrm{F}_{2}$ folds. The deformation was so intense that most fold axes were transposed parallel to the NW-SE oriented direction of extension (see stereoplots on Plate 1). The NW-verging third phase structures $\left(\mathrm{S}_{3}, \mathrm{~L}_{3}, \mathrm{~F}_{3}\right)$ are similar to the second phase structures, but the geometry of the more open $\mathrm{F}_{3}$ folds suggest that this deformation occurred under lower temperature conditions, resulting from cooling by regional uplift and erosion or from dehydration and/or water loss during deformation. In contrast, the structures of the next phase of NW-directed thrusting suggest more brittle rock behaviour at lower temperature conditions. NW-verging $\mathrm{F}_{4}$ folds are rare. They result from the continuation of the NW-verging rotational deformation (Fig. 11). Two sets of shear bands, a shallow dipping $S_{5^{\prime}}$ and a steeper $\mathrm{S}_{5^{\prime \prime}}$ set of shear band cleavages, with their SE-dipping $L_{5^{\prime}}$ and $\mathrm{L}_{5}$ " stretching lineations, overprinted the pre-existing intense S1-S3 mylonite foliation. The gneiss slab of Unit II of the Jungfrau syncline was affected at the hectometric to kilometric scale by an asymmetric extensional boudinage (Plate 1, Figs. 5 and 12). The Gastern dome structure, which affects the Jungfrau syncline, was developed during a late phase of Gastern-Aar back folding (Fig. 3; Steck et al. 1979; Steck 1984; "Grindelwald phase" of Burkhard 1988).

In summary, the Jungfrau syncline corresponds to the intensely sheared and stretched overturned limb of the Doldenhorn fold nappe. Up to 5 planar structures, - schistosities $S_{1}$ and $S_{2}$, crenulation cleavage $S_{3}$ and shear planes $S_{5^{\prime}}$ and $S_{5^{\prime \prime}}-$ developed during the progressive NW-verging rotational deformation in the Jungfrau syncline, while in the frontal Doldenhorn fold hinge only a single axial surface cleavage was developed
(Schläppi 1980). This example demonstrates that the use of fold phases as time markers for the Infrahelvetic and Helvetic nappes, in which our study area is situated, is not appropriate or has to be applied with much caution.

\section{Conclusions}

From our study of the excellent outcrops of the Jungfrau syncline in the Faflertal and our knowledge of regional structural relations, we propose the following model. The formation of the Doldenhorn fold nappe started by extrusion of the Mesozoic sediments of the Doldenhorn basin during the early underthrusting of that basin. The calcareous Mesozoic sediments were squeezed out and transported during the NW-directed overthrusting of the higher Helvetic and the Penninic nappes. A first schistosity $S_{1}$ developed in this early phase in the southern Doldenhorn basin (Fig. 15). The $F_{2}$ folds of the Aar massif basement and the Jungfrau syncline were created at a later stage, in a regime of ductile basement rheology at temperatures above $300{ }^{\circ} \mathrm{C}$, by a mechanism of crystal plastic creep and dynamic recristallization of quartz-rich gneisses. The basement gneiss folds reflect ductile folding of the contact between the more viscous basement gneiss and the very ductile sedimentary cover composed of Mesozoic marbles and marly limestones. The pre-existing SE-dipping normal faults, limiting the Doldenhorn sedimentary basin, do not appear to have been reactivated as reverse faults during Alpine compression. Top-to-the-NW shear band cleavages and thrust faults developed only in a late phase of Alpine compression, under lower temperature and more brittle conditions, after a late regional uplift and erosion of the nappes that overthrust the Aar and Gastern massifs. In a wider perspective, we suggest that the Mont Blanc basement fold (Epard 1990) and the Aar and Gotthard folds, with their frontal folds that coincide with the anchi-epizone boundary (Steck et al. 2001; Steck 2008) were created at high temperatures and below a $10-25 \mathrm{~km}$ thick nappe stack by ductile folding and detachment of upper parts of the European crust during its underthrusting below the Adriatic plate. We think it is probable that the lower and middle Penninic Antigorio, Monte Leone, Pontis-Berisal and Siviez-Mischabel fold nappes (Steck 1984, 87; Escher et al. 1993, 1997; Genier et al. 2008) were formed by a similar mechanism.

\section{Acknowledgments}

Neil Mancktelow, Geoffrey Milnes and Adrian Pfiffner are thanked for their critical reading of the manuscript. Jean-Luc Epard and Henri Masson of the Lausanne Alpine working group contributed to this study by fruitful discussions on the outcrop and in the laboratory.

\section{REFERENCES}

Aramowicz, A., Cosca, M., Stöckli, D. 2007: High exhumation rates in the Aar massif, revealed by zircon $(\mathrm{U}-\mathrm{Th}) / \mathrm{He}$ thermochronology, $5^{\text {th }}$ Swiss Geoscience Meeting, Geneva 2007, Abstract volume, p14. 
Argand, E. 1911: Les nappes de recouvrement des Alpes Pennines et leurs prolongements structuraux. Beiträge zur Geologischen Karte der Schweiz [N.F.] 31, 26 pp.

Argand, E. 1916: Sur l'arc des Alpes Occidentales. Eclogae Geologicae Helvetiae 14, 145-204.

Berthé, D., Choukroune, P., Jegouzo, P. 1979: Orthogneiss, mylonite and noncoaxial deformation of granites: the example of the South Armorican shear zone. Journal of Structural Geology 1, 31-42.

Boyer, S.E., Elliott, D. 1982: Thrust systems. American Association of Petroleum Geologists Bulletin 66, 1196-1230.

Bucher, K., Frey, M. 1994: Petrogenesis of Metamorphic Rocks. Springer, Berlin.

Bugnon, P.C. 1986: Geologie de l'Helvétique à l'extrémité sud-ouest du massif de l'Aar (Loeche, Valais). Ph. D. thesis, University of Lausanne.

Burkhard. M. 1988: L'Helvétique de la bordure occidentale du massif de l'Aar (evolution tectonique et métamorphique). Eclogae Geologicae Helvetiae 81, 63-114.

Burkhard, M. 1990: Aspects of the large-scale Miocene deformation in the most external part of the Swiss Alps (Subalpine Molasse to Jura fold belt) Eclogae Geologicae Helvetiae 83, 559-584.

Butler, R.W.H., Matthews, S.J.,Parish, M.1986:The NW external Alpine thrust belt and its implications for the geometry of the western Alpine orogen. In Collision Tectonics, edited by M.P. Coward and A.C. Ries. Special Publication of the Geological Society 19, 245-260.

Butler, R.W.H. 1990: Balanced sections on a crustal scale: a view from the Western Alps. In Proceedings of the Sixth Workshop on the European Geotraverse (EGT) Project, edited by R. Freeman and S. Mueller. European Science Foundation Strasbourg, 157-164.

Collet, l.W., Paréjas, E. 1931: Géologie de la Chaîne de la Jungfrau. Matériaux Carte géologique Suisse, NS. 63.

Crestin, G. 1990: Geologie du Lötschenpass. Unpublished Diploma thesis, Université de Lausanne.

Dolivo, E. 1982: Nouvelles observations structurales au SW du massif de l'Aar entre Visp et Gampel. Ph.D. thesis, University of Lausanne.

Epard, J.-L. 1990: La nappe de Morcles au sud-ouest du Mont-Blanc. Mémoires de Géologie, Lausanne 3,1-165.

Epard, J.-L., Escher, A. 1996: Transition from basement to cover: A geometric model. Journal of Structural Geology 18, 533-548.

Escher, A., Beaumont, C. 1997: Formation, burial and exhumation of basement nappes at crustal scale: A geometric model based on the western Swiss-Italian Alps. Journal of Structural Geology 19, 955974.

Escher,A., Hunziker, J., Marthaler, M., Masson, H., Sartori, M., Steck, A. 1997: Geologic framework and structural evolution of the western SwissItalian Alps. In Deep Structure of the Swiss Alps: Results of NRP 20, edited by O.A. Pfiffner, P. Lehner, P. Heitzmann, S. Mueller and A. Steck. Birkhäuser Verlag Basel, 205-221.

Escher, A., Masson, H., Steck, A. 1988: Coupes géologiques à travers la partie centrale des Alpes occidentales suisses. Rapports géologiques, Service Hydrologie et Geologie National Suisse 2,1-11.

Escher, A., Masson, H., Steck, A. 1993: Nappe geometry in the Western Swiss Alps. Journal of Structural Geology 15, 501-509.

Frank, E. 1983: Alpine metamorphism of calcareous rocks along a cross-section in the Central Alps: occurence and breakdown of muscovite, margarite and paragonite. Schweizerische Mineralogisch Petrographische Mitteilungen 63,37-93.

Frey, M. 1968: Quartenschiefer, Equisetenschiefer und germanischer Keuper - ein lithostratigraphischer Vergleich. Eclogae Geologicae Helvetiae 61, $141-156$.

Frey, M. 1969: Die Metamorphose des Keupers vom Tafeljura bis zum Lukmaniergebiet. Beiträge Geologische Karte Schweiz 137, 1-160.

Frey, M. \& Wieland, B. 1975: Chloritoid in autochthon-parautochthonen Sedimenten des Aarmassivs. Schweizerische Mineralogisch Petrographische Mitteilungen 55, 407-418.

Genier, F., Epard, J.-L., Bussy, F., Magna, T. 2008: Lithostratigraphy and U-Pb zircon dating in the overturned limb of the Siviez-Mischabel nappe; a new key for Middle Penninic nappe geometry. Swiss Journal of Geosciences 101/2, 431-452.
Hänni, R., Pfiffner, O.A. 2001: Evolution and internal structure of the Helvetic nappes in the Bernese Oberland. Eclogae Geologicae Helvetiae 94, 161-171.

Herweg, M., Pfiffner, O.A. 2005: Tectonometamorphic evolution of a nappe stack: A case study of the Swiss Alps. Tectonophysics 404, 55-76.

Hügi, Th., Ledermann, H. \& Schläppi,E. 1988: Geol. Atlas der Schweiz, 1:25'000, 1268 Lötschental und Erläuterungen. Schweizerische Geologische Kommission und Landeshydrologie und -geologie, Bern.

Kellerhals, P., Isler A. 1998: Lötschberg-Basistunnel: Geologische Voruntersuchungen und Prognose. Geologische Berichte 22, Landeshydrologie und -geologie.

Kirschner, D.L., Sharp, Z.D., Masson. H. 1995: Oxygen isotope thermometry on quartz-calcite veins: Unraveling the thermal-tectonic history of the subgreenschist facies Morcles nappe (Swiss Alps). Bulletin Geological Society of America 107, 1145-1156.

Kirschner, D.L., Cosca, M.A., Masson, H., Hunziker, J.C. 1996: Staircase 40Ar/ 39Ar spectra of fine grained white mica:Timing and duration of deformation and empirical constraints on argon diffusion. Geology 24, 747-750.

Kirschner, D.L., Masson. H., Cosaca, M.A. 2003: An 40Ar/39Ar, Rb/Sr, and stable isotope study of micas in low-grade fold-and-thrust belt: an example from the Swiss Helvetic Alps. Contributions to Mineralogy and Petrology 145, 460-480.

Krayenbuhl, Th. 1984: Geologie de l'Innerfaflertal et du Lötschberg. unpublished Diploma thesis, Lausanne.

Krebs, J. 1925: Geologische Beschreibung der Blümlisalpgruppe. Beiträge Geologische Karte Schweiz. N.F. 54.

Lugeon, M. 1914-1918: Les Hautes Alpes calcaires entre la Lizerne et la Kander. Matériaux Carte géologique Suisse, nouvelle Série, Livraison 30 avec carte spéciale No. 60 (1910).

Loup, B. 1992: Evolution de la partie septentrionale du domaine helvétique en Suisse occidentale au Trias et au Lias: contrôle par subsidence thermique et variations du niveau marin. Ph. D. Thesis, Publications du Département de Géologie et de Paléontologie, Université de Genève, 12.

Marquer, D. 1990: Structures et deformation alpine dans les granites hercyniens du massif du Gothard (Alpes centrals suisses). Eclogae Geologicae Helvetiae 83,77-97.

Masson, H., Herb, R. and Steck, A. 1980. Helvetic Alps of Western Switzerland. In: R. Trümpy (Ed.): Geology of Switzerland, part B. Wepf \& Co. Basel, 109-135.

Milnes, A.G. \& Pfiffner, A. 1977: Structural development of the Infrahelvetic complex, eastern Switzerland. Eclogae Geologicae Helvetiae 70, 83-95.

Passchier, C.W. \& Trouw, R.A.J. 1996: Microtectonics. Springer, Berlin.

Pfiffner, O.A. \& Heitzmann, P. 1997a: Geologic interpretation of the seismic profiles of the Central Traverse (lines C1, C2, C3 north). In Deep Structure of the Swiss Alps: Results of NRP 20, edited by O.A. Pfiffner, P. Lehner, P. Heitzmann, S. Mueller and A. Steck. Birkhäuser Verlag Basel, 115-122.

Pfiffner, O.A., Sahli, S. \& Stäuble, M. 1997b: Structure and evolution of the external basement uplifts (Aar, Aiguilles Rouges/Mt. Blanc). In Deep Structure of the Swiss Alps: Results of NRP 20, edited by O.A. Pfiffner, P. Lehner, P. Heitzmann, S. Mueller and A. Steck. Birkhäuser Verlag Basel, 139-153.

Pfiffner, O.A., Lehner, P., Heitzmann, P., Mueller, St. and Steck A. 1997: Deep Structure of the Alps: Results of NRP 20. Birkhäuser Verlag Basel.

Platt, J.P., Vissers, R.L.M. 1980: Extensional structures in anisotropic rocks. Journal of Structural Geology 2, 397-410.

Ramsay, J.G. 1967: Folding and Fracturing of Rocks. McGraw-Hill, New York.

Ramsay, J.G. 1980: Shear zone geometry: a review. Journal of Structural Geology 2, 83-99.

Ruffini, R., Cosca, M.A., D’Atri, A., Hunziker, I.C., Polino, R. 1995:The volcanic supply of the Taveyanne turbidites (Savoie, France): a riddle for Tertiary Alpine volcanism. Atti Convegno rapporti Alpi-Appennino (Roma) 14, 359-376.

Ruffini, R., Polino, R., Callegary, E., Hunziker, I.C., Pfeifer, H.R. 1997: Volcanic clast rich turbidites of the Taveyanne sandstones from the Thônes syncline (Savoie, France): records for Tertiary postcollisional volcanism. Schweizerische Mineralogisch Petrographische Mitteilungen 77, 161174.

454 T. Krayenbuhl \& A. Steck 
Rutishauser, H., Hügi, Th. 1978: Der Kontakt zwischen Gasterngranit und Lauterbrunner Kristallin im Gasterntal (Aarmassiv, Schweiz). Mitteilungen der Naturforschenden Gesellschaft Bern (N.F.) 35,1-53.

Schaltegger, U. 1993: The evolution of the polymetamorphic basement of the Central Alps unravelled by precise U-Pb zircon dating. Contributions to Mineralogy and Petrology 113, 466-478.

Schläppi, E. 1980: Geologische und tektonische Entwicklung der DoldenhornDecke und zugehöriger Elemente. Ph.D. thesis, University of Bern.

Steck, A. 1968: Die alpidischen Strukturen in den Zentralen Aaregraniten des westlichen Aarmassivs. Eclogae Geologicae Helvetiae 61, 19-48.

Steck, A. 1984: Structures de déformations tertiaires dans les Alpes centrales (transversale Aar-Simplon-Ossola). Eclogae Geologicae Helvetiae 77, $55-100$.

Steck, A. 1987: Le massif du Simplon - Réflexions sur la cinématique des nappes de gneiss. Schweizerische Mineralogisch Petrographische Mitteilungen 67, 27-45.

Steck, A. 1990: Une carte des zones de cisaillement ductile des Alpes Centrales. Eclogae Geologicae Helvetiae 83, 603-627.

Steck, A. and Burri, G. 1971: Chemismus und Paragenesen von Granaten aus Granitgneisen der Grünschiefer- und Amphibolitfazies der Zentralalpen. Schweizerische Mineralogisch Petrographische Mitteilungen 51, in Bericht über die 46. Hauptversammlung in Fribourg, 1-4.

Steck, A., Epard, J.L., Escher, A., Marchant, R., Masson, H., Spring, L. 1989: Coupe tectonique horizontale des Alpes centrales. Mémoires de Géologie (Lausanne) 5.

Steck, A., Bigioggero, B., Dal Piaz, G.V., Escher, A., Martinotti, G., Masson, H. 1999: Carte géologique des Alpes de Suisse occidentale, 1:100'000. Carte géologique spéciale $\mathrm{N}^{\circ} 123$. Service d’Hydrologie et Géologie Nationale (Berne).

Steck, A., Epard, J.-L., Escher, A., Gouffon, Y., Masson, H. 2001: Notice explicative de la Carte géologique des Alpes de Suisse occidentale 1:100'000. Carte géologique spéciale $\mathrm{N}^{\circ} 123$. Office fédéral Eaux et Géologie (Berne).

Steck, A., Ramsey, J.G., Milnes, A.G., Burri, M. 1979: Compte rendu de l'excursion de la Société Géologique Suisse et la Société de Minéralogie et Pétrographie en Valais et en Italie nord du 2 au 5 octobre 1978. Eclogae Geologicae Helvetiae 72, 287-311.

Steck, A., Hunziker, J. 1994: The Tertiary structural and thermal evolution of the Central Alps - compressional and extensional structures in an orogenic belt. Tectonophysics 238, 229-254.

Stipp, M., Stünitz, H., Heilbronner, R., Schmid, St., 2002: Dynamic recrystallisation of quartz: correlation between natural and experimental conditions. Geological Society of London, Special Publication 200,171-190.

Trümpy, R. 1980: Geology of Switzerland. Schweizerische Geologische Kommission, Wepf \& Co, Basel.

Voll, G. 1976: Recrystallisation of quartz, biotite and feldspars from Erstfeld to the Leventina Nappe, Swiss Alps, and its geological significance. Schweizerische Mineralogisch Petrographische Mitteilungen 56, 641647.

Manuscript received September 12, 2008

Revision accepted August 8,2009

Published Online first November 30, 2009

Editorial Handling: A. G. Milnes 


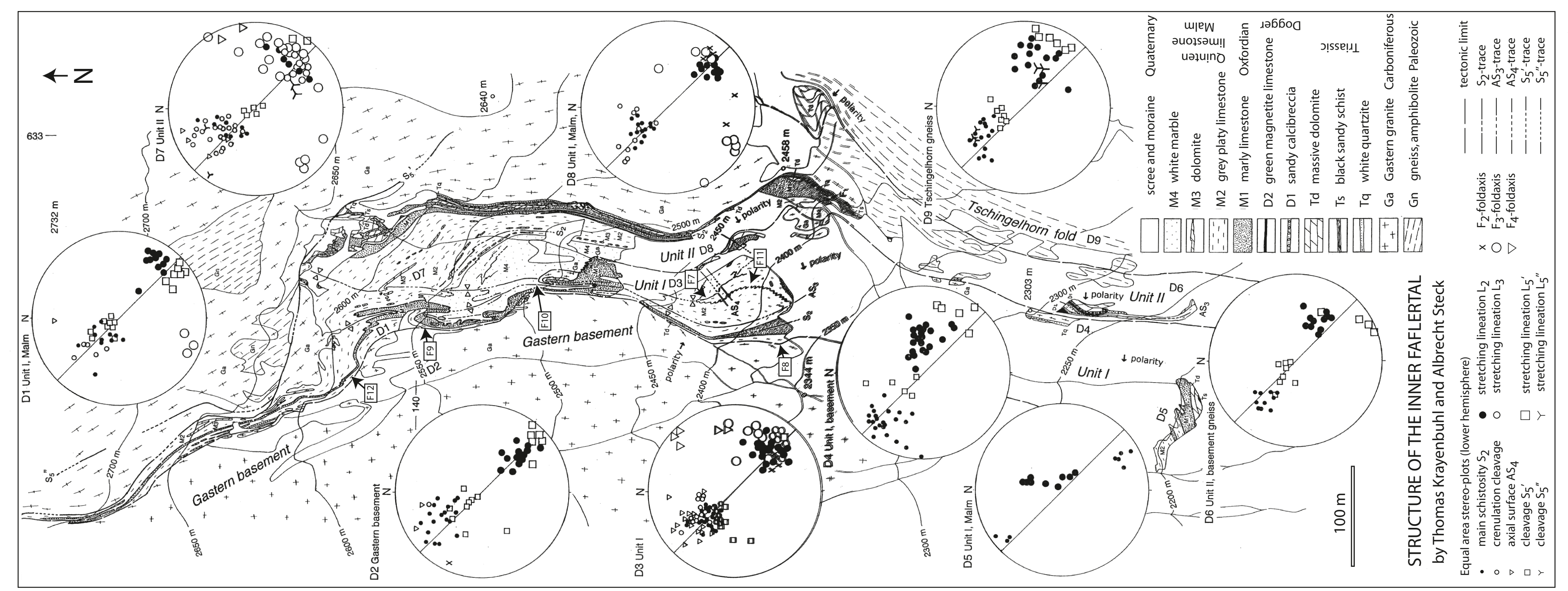

Plate 1: Structural map of the Inner Fafler valley after Krayenbuhl (1984). F7-F12 indicate the localities of Figures 7-12. 